\title{
Synthesis, Characterization and Study of Phenol Adsorption Over MnOx- $\mathrm{CeO}_{2}$
}

\author{
Oriana. D’Alessandro, Horacio Thomas and Jorge Sambeth ${ }^{*}$
}

Centro de Investigación y Desarrollo en Ciencias Aplicadas "Dr. Jorge J. Ronco" CINDECA - FCE, UNLP, CCT CONICET LA PLATA - $47 N^{\circ} 257$ (1900) La Plata, Argentina

\begin{abstract}
Five $\mathrm{MnOx}-\mathrm{CeO}_{2}$ samples with a molar ratio $\mathrm{Mn}-\mathrm{Ce}$ between 0 and $100 \%$ were obtained by coprecipitation. The samples, which were called 10/0,7/3, 5/5, 3/7, 0/10, were characterized by XRD, FTIR, XPS, specific surface area and TPR. Phenol was selected as pollutant. The adsorption of phenol from aqueous solution on Mn-Ce samples was carried out in a batch reactor at 25 and $50^{\circ} \mathrm{C}$. The adsorption isotherms were described by Langmuir and Freundlich isotherm models and both model fitted. The characterization results showed the formation of solid solution where $\mathrm{Mn}^{3+}$ replaces $\mathrm{Ce}^{4+}$. The most active solid was $\mathrm{Mn}-\mathrm{Ce} 7 / 3$. The results showed that the adsorption process is a function of the MnCe composition. Thermodynamics parameters $\Delta \mathrm{G}^{0}, \Delta \mathrm{H}^{0}$ and $\Delta \mathrm{S}^{0}$ were calculated. These parameters indicated that the adsorption of phenol onto Mn-Ce was spontaneous and exothermic at 25 and $50^{\circ} \mathrm{C}$.
\end{abstract}

Keywords: Adsorption, phenol, $\mathrm{MnOx}-\mathrm{CeO}_{2}$.

\section{INTRODUCTION}

Many industrial processes produce wastewater containing different pollutants such as phenol, benzene, aldehydes, acids, and aromatic polycyclic compounds. In many cases, these pollutants are dangerous at a low concentration of the order of a few ppm [1].

Techniques such as incineration and adsorptive separation can be used according to Busca [2]. However, both methods have secondary problems. For example, combustion produces the formation of particulate material and gaseous pollutants (CO, NOx, etc.). Imamura, Hamoudi and other authors have proposed Catalytic Wet Air Oxidation (CWAO) as an alternative technique to liquid effluent treatment $[3,4]$.

The heterogeneous catalytic processes have demonstrated to be a good technique, mainly because the processes do not need any extra separation. Noble metals and oxides of the transition metal have been tested with different types of toxic effluents [5]. The physicochemical properties of the catalysts (oxidation state, formation of the redox pairs, etc.) are important in the selection of the oxidation catalyst. For this reason, $\mathrm{MnOx}-\mathrm{CeO}_{2}$ catalysts are widely used in CWAO processes with experimental conditions such as reaction temperature between 100 and $200{ }^{\circ} \mathrm{C}$, pressure between 3 and $35 \mathrm{~atm}$. These reaction conditions allow us to obtain biodegradable intermediaries, $\mathrm{CO}_{2}$ and $\mathrm{H}_{2} \mathrm{O}$ with a conversion near $100 \%$ [6].

The first steps of the catalytic process is the adsorption and the formation of adsorbed species, for this reason the

*Address correspondence to this author at the Centro de Investigación y Desarrollo en Ciencias Aplicadas "Dr. Jorge J. Ronco" CINDECA - FCE, UNLP, CCT CONICET LA PLATA - 47 N 257 (1900) La Plata, Argentina; Tel: +54-221-4211353;

E-mail: sambeth@quimica.unlp.edu.ar aim of this paper is: (i) to analyze the adsorption of phenol on five mesoporous solids $\mathrm{MnOx}-\mathrm{CeO}_{2}$ obtained by alkaline coprecipitation and (ii) to correlate the adsorption capacity with the physicochemical properties of the solids.

\section{EXPERIMENTAL}

Synthesis: Manganese-cerium composites were prepared by the coprecipitation method using $\mathrm{Ce}\left(\mathrm{NO}_{3}\right)_{3} \cdot 6 \mathrm{H}_{2} \mathrm{O}$ (SigmaAldrich), $\mathrm{Mn}\left(\mathrm{NO}_{3}\right)_{2} \cdot 4 \mathrm{H}_{2} \mathrm{O}$ (Anedra) and $\mathrm{NaOH}$ (Carlo Erba) solutions. The samples were prepared with molar ratios (MnCe) $10 / 0$ (pure manganese oxide), $7 / 3,5 / 5,3 / 7$ and $0 / 10$ (pure cerium oxide). The solids were dried at $100{ }^{\circ} \mathrm{C}$ and calcined in air at $350{ }^{\circ} \mathrm{C}$ for $3 \mathrm{~h} \mathrm{[7]}$.

Characterization: XRD spectra were recorded on Philips PW 1390 using K $\alpha$ radiation. FTIR spectra were measured on Bruker IFS 66 with a Globar source accumulating 32 scans at a resolution of $4 \mathrm{~cm}^{-1}$. XPS spectra were analyzed with a system of multi-technical equipment Phoibos 150, the specific surface areas of the catalysts were determined using $\mathrm{N}_{2}$ adsorption and the BET model using the Micromeritics ASAP 2020. TPR was carried out using a Quantachrome Quantasorb Jr. instrument and $\mathrm{CuO}$ as patron.

Adsorption study: The adsorption experiments were carried out using the batch technique. For each isotherm $50 \mathrm{mg}$ of Mn-Ce oxide and $5 \mathrm{~g} / \mathrm{mL}$ of phenol solution of given concentrations between 0.125 and $1 \mathrm{~g} / \mathrm{L}$ were used. The adsorption temperature was $25^{\circ} \mathrm{C}$ and $50^{\circ} \mathrm{C}$. The suspensions were mixed on a rotary tumbler for $24 \mathrm{~h}(27.3 \mathrm{rpm})$. The phenol removal was monitored by UV-VIS spectroscopy in a Perkin-Elmer Lambda 35.

\section{RESULTS AND DISCUSSION}

The results of the XRD characterization indicate: (i) for $\mathrm{Mn}-\mathrm{Ce}$ 10/0, the formation of $\mathrm{Mn}_{2} \mathrm{O}_{3}$ (JCPDS \# 06-0540), $\mathrm{MnO}_{2}$ (JCPDS \# 39-0375), $\mathrm{Mn}_{3} \mathrm{O}_{4}$ (JCPDS \# 18 - 0803) and 


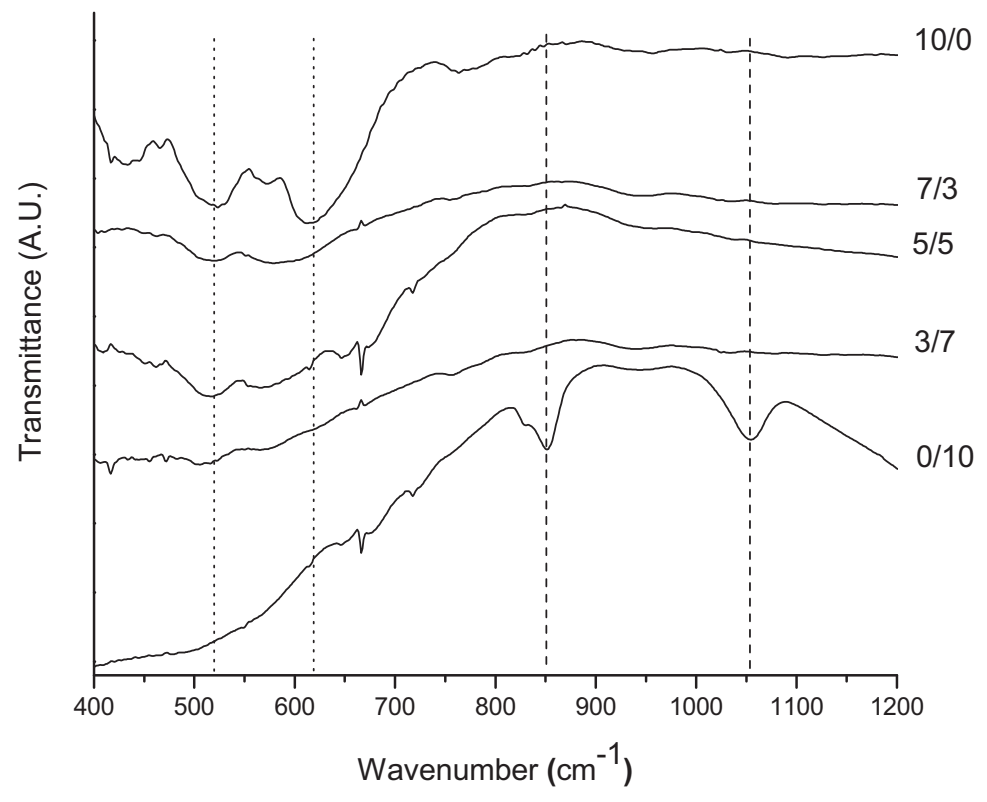

Fig. (1). IR spectra for Mn-Ce samples: ( $\cdots) \mathrm{MnO}_{\mathrm{x}}$ and (---) $\mathrm{CeO}_{2}$.

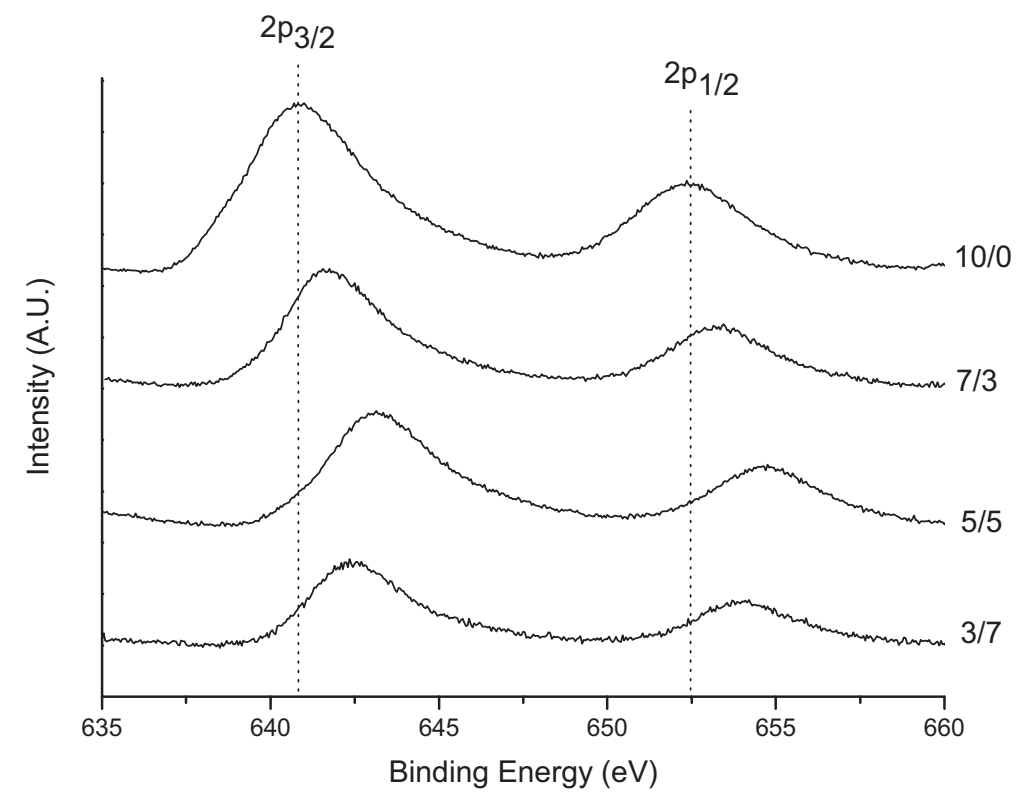

Fig. (2). XPS spectra of Mn $2 \mathrm{p}$ region.

$\mathrm{Mn}_{5} \mathrm{O}_{8}$ (JCPDS \# 39-1218), (ii) for Mn-Ce 0/10, the presence of $\mathrm{CeO}_{2}$ phase with fluorite structure (JCPDS \# 431002), and (iii) for $\mathrm{Mn}-\mathrm{Ce} 7 / 3,5 / 5$ and $3 / 7$ solids, broad peaks due to $\mathrm{CeO}_{2}$ with a fluorite structure, which may indicate the formation of a solid solution where $\mathrm{Mn}^{3+}$ replaces $\mathrm{Ce}^{4+}$ [8]. Fig. (1) illustrates the FTIR spectra of the samples. The solids with Mn present two strong bands, one of them at $520 \mathrm{~cm}^{-1}$ and the other at $615 \mathrm{~cm}^{-1}$. These bands are associated with the antisymmetric stresses O-Mn-O [9]. As can be seen in the $7 / 3,5 / 5$ and $3 / 7$ samples, the band at $615 \mathrm{~cm}^{-1}$ has shifted. This shift could be due to distortion of the $\mathrm{MnO}_{6}$ octahedra. In the $\mathrm{Mn}-\mathrm{Ce} 0 / 10$ sample the bands corresponding to $\mathrm{O}-\mathrm{Ce}-\mathrm{O}$ and $\mathrm{O}-\mathrm{Ce}-\mathrm{OH}$ at 850 and $1050 \mathrm{~cm}^{-1}$, respectively, are detected [10].
Fig. (2) shows the XPS spectra of Mn 2p in the samples with Mn show a broad band at $640.7 \mathrm{eV}$, which could be associated with the oxidation states $\mathrm{Mn}^{2+}, \mathrm{Mn}^{3+}$ and $\mathrm{Mn}^{4+}$ [11]. Table 1 lists the binding energy (BE) of the bands Mn $2 \mathrm{p} 3 / 2$ and $2 \mathrm{p} 1 / 2$. As can be seen, between the samples $10 / 0$ and $5 / 5$ there is a shift towards higher energies of $2.4 \mathrm{eV}$, which can indicate a strong interaction between $\mathrm{Mn}$ and $\mathrm{Ce}$ [12]. The Mn-Ce 3/7 solid shows a lower shift than the other solids. We suggest that this phenomenon should be associated with a decreased Mn-Ce interaction, which could be due to low Mn concentration. Table 1 also shows the average oxidation states (AOS) for each sample. The determination of the average oxidation state of manganese was calculated according to [13], and the results allow us to show the presence of $\mathrm{Mn}^{3+}-\mathrm{Mn}^{4+}$. 
Table 1. Binding Energies (BE) of Mn 2p3/2, 2p1/2 and Average Oxidation State (AOS) of Mn.

\begin{tabular}{|c|c|c|c|}
\hline Sample & BE Mn 2 $\mathbf{p}_{3 / 2}(\mathbf{e V})$ & BE Mn 2 $\mathbf{p}_{\mathbf{1} / 2}(\mathbf{e V})$ & AOS \\
\hline \hline Mn-Ce 10/0 & 640.7 & 652.3 & 3.69 \\
\hline Mn-Ce 7/3 & 641.7 & 653.4 & 3.42 \\
\hline Mn-Ce 5/5 & 643.1 & 654.7 & 3.63 \\
\hline Mn-Ce 3/7 & 642.3 & 654.2 & 3.29 \\
\hline
\end{tabular}

Table 2. Binding Energies (BE) of Both Types of Oxygen as well as their Percentage in Each Sample.

\begin{tabular}{|c|c|c|c|c|}
\hline Sample & $\operatorname{BE} O_{a}(\mathrm{eV})$ & $\mathrm{BE} O_{\beta}(\mathrm{eV})$ & $\mathbf{O}_{\alpha}(\%)$ & $\mathbf{O}_{\beta}(\%)$ \\
\hline Mn-Ce 10/0 & 528.5 & 530.1 & 54.7 & 45.3 \\
\hline $\mathrm{Mn}-\mathrm{Ce} 7 / 3$ & 530.1 & 531.9 & 69.7 & 31.3 \\
\hline $\mathrm{Mn}-\mathrm{Ce} 5 / 5$ & 530.7 & 532.3 & 71.3 & 28.7 \\
\hline Mn-Ce 3/7 & 530.8 & 531.9 & 58.1 & 41.9 \\
\hline Mn-Ce $0 / 10$ & 531.1 & 533.1 & 58.5 & 41.5 \\
\hline
\end{tabular}

Table 3. Pore Volume, Specific Surface Area and Pore Size of Mn-Ce Samples.

\begin{tabular}{|c|c|c|c|}
\hline Sample & Pore Volume $\left(\mathrm{cm}^{3} / \mathbf{g}\right)$ & Surface Area $\left(\mathbf{m}^{2} / \mathbf{g}\right)$ & Pore size $(\mathbf{A})$ \\
\hline \hline Mn-Ce 10/0 & 0.145 & 22 & 148 \\
\hline Mn-Ce 7/3 & 0.331 & 63 & 167 \\
\hline Mn-Ce 5/5 & 0.456 & 87 & 182 \\
\hline Mn-Ce 3/7 & 0.460 & 96 & 179 \\
\hline Mn-Ce 0/10 & 0.241 & 137 & 68 \\
\hline
\end{tabular}

The $\mathrm{O} 1 \mathrm{~s}$ region shows two different oxygen species. The $\mathrm{BE}$ of 529-530 eV may be associated lattice oxygen $\left(\mathrm{O}^{2-}\right)$, denoted as $\mathrm{O} \alpha$, and the $\mathrm{BE}$ of 531-532 eV might be assigned to defect oxide or $\mathrm{OH}$, called $\mathrm{O}_{\beta}[14]$. Table 2 shows the $\mathrm{BE}$ of both types of oxygen and their percentages.

The results demonstrated that the amount of $\mathrm{O}_{\alpha}$ is higher than that of $\mathrm{O}_{\beta}$ and the $\mathrm{Mn}-\mathrm{Ce} 5 / 5$ solid shows the greatest percentages. With the addition of $\mathrm{Ce}$, the $\mathrm{O}_{\alpha}$ band is shifted to higher energies $(2.3 \mathrm{eV}$ maximum displacement in the Mn-Ce 3/7 sample).

With respect to $\mathrm{Ce}$, the study of $\mathrm{Ce} 3 \mathrm{~d}$ region indicates the presence of three bands at 879-890 eV, 895-913 eV and 918 $\mathrm{eV}$. These bands may suggest the presence of $\mathrm{Ce}^{3+}$ and $\mathrm{Ce}^{4+}$ species [15]; in particular, the component around $916 \mathrm{eV}$ is assigned to the formation of $\mathrm{Ce}^{4+}[16]$.

The $\mathrm{N}_{2}$ adsorption-desorption isotherm demonstrates that the solids have a mesoporous structure. The surface areas, pore volumes and pore size are summarized in Table 3. The results show that the structural properties are a function of $\mathrm{Ce}$ in the Mn-Ce mixed.

The TPR technique (Fig. 3) showed two reduction peaks at $338{ }^{\circ} \mathrm{C}$ and $464{ }^{\circ} \mathrm{C}$ for the sample Mn-Ce 10/0, which can be assigned to $\mathrm{Mn}_{2} \mathrm{O}_{3}$ and $\mathrm{Mn}_{3} \mathrm{O}_{4}$ respectively. If we com- pare the reduction temperatures of $\mathrm{Mn}-\mathrm{Ce} 10 / 0$ and $0 / 10$ with the reduction temperature of the $\mathrm{Mn}-\mathrm{Ce} 7 / 3,5 / 5$ and 3/7 samples, around 318 and $418{ }^{\circ} \mathrm{C}$, we can see a systematic shift at lower temperatures. According to [17] this phenomenon indicates a higher mobility of oxygen associated with an improvement in the redox properties of the system. The lower temperatures for the reduction peaks of $\mathrm{Mn}-\mathrm{Ce} 7 / 3$, $5 / 5$ and $3 / 7$ samples compared to those of the Mn-Ce $10 / 0$ indicated that the manganese species with higher oxidation states were easily reduced. The reduction profile for sample Mn-Ce 0/10 shows one reduction peak between 338 and 568 ${ }^{\circ} \mathrm{C}$ at very low intensity and the other at $794{ }^{\circ} \mathrm{C}$. The first peak is associated with the reduction in surface and the other with bulk reduction [18].

Fig. (4) shows the results of the adsorption study. As can be seen, the process is favorable at both temperatures. Over $\mathrm{Mn}-\mathrm{Ce}$ 10/0 and 0/10 phenol adsorption is negligible.

The structural and spectroscopic characterization allows us to say that: (i) Mn-Ce form a solid solution, where $\mathrm{Mn}^{3+}$ $\left(r_{\text {ionic }}=0.085 \mathrm{~nm}\right)$ replaces $\mathrm{Ce}^{4+}\left(\mathrm{r}_{\text {ionic }}=0.098 \mathrm{~nm}\right)$, (ii) the reducibility of $\mathrm{Mn}$ species is enhanced when it is present in the $\mathrm{CeO}_{2}$ structure and (iii) the presence of redox pairs $\mathrm{Mn}^{3+} / \mathrm{Mn}^{+4}$ and $\mathrm{Ce}^{3+} / \mathrm{Ce}^{4+}$. 


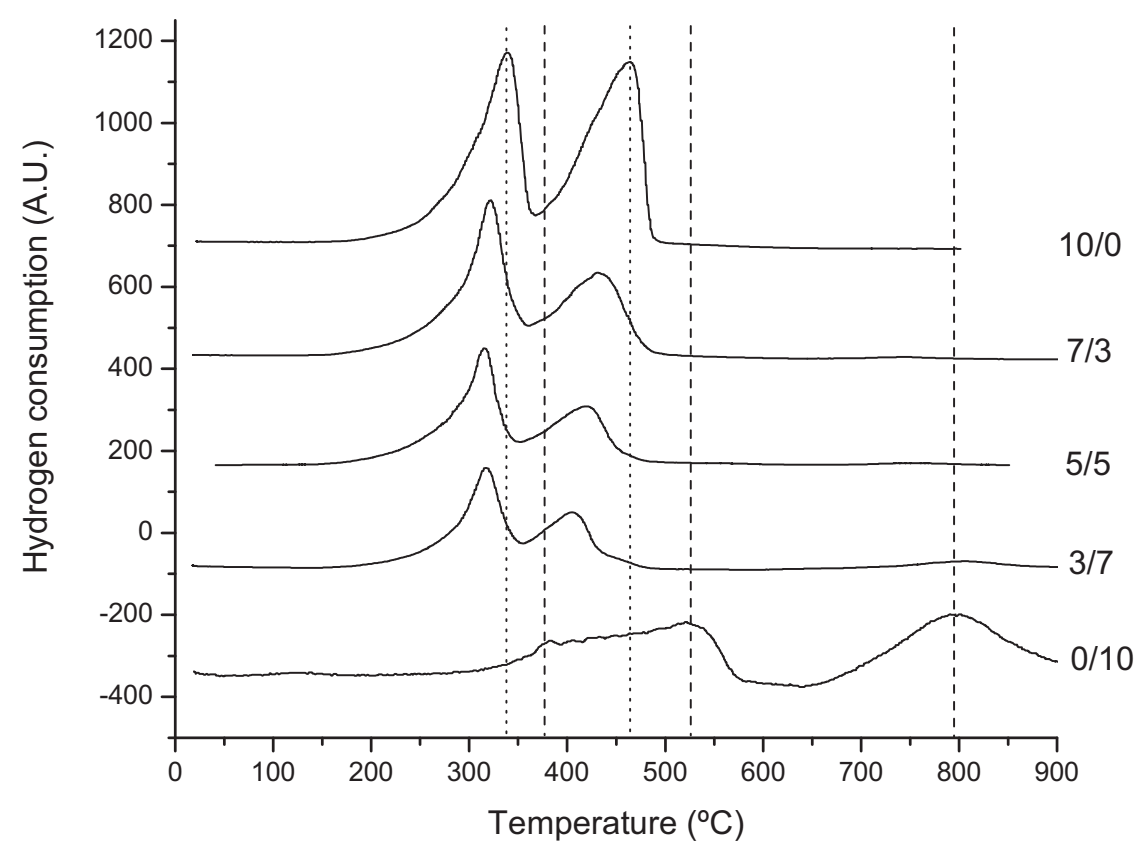

Fig. (3). $\mathrm{H}_{2}$-TPR profiles of Mn-Ce solids: ( $\left.\cdots\right) \mathrm{MnO}_{\mathrm{x}}$ and (---) $\mathrm{CeO}_{2}$.

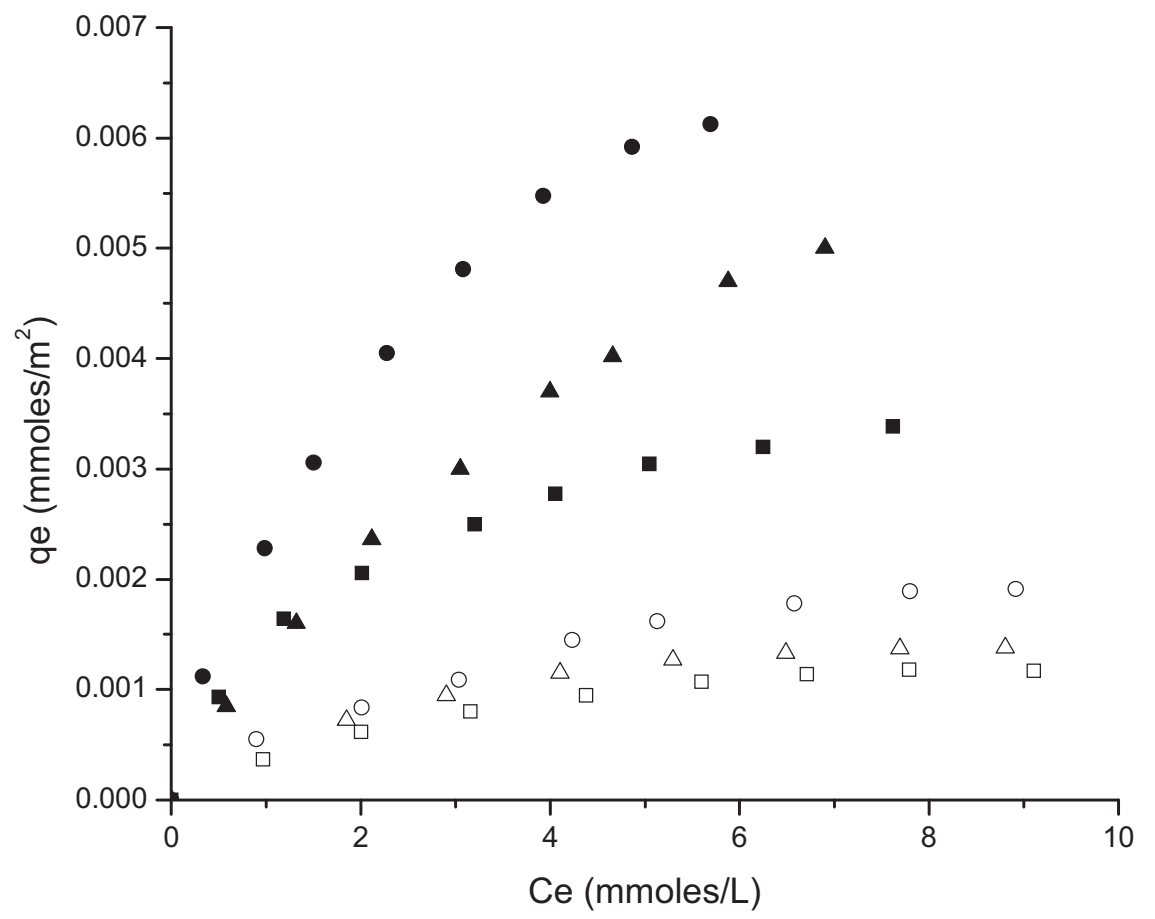

Fig. (4). phenol adsorption isotherms at $25^{\circ} \mathrm{C}$ and $50{ }^{\circ} \mathrm{C}$.

- Mn-Ce 7/3, $\Delta$ Mn-Ce 3/7 and - Mn-Ce $5 / 5$ at $50^{\circ} \mathrm{C}$;

$\circ \mathrm{Mn}-\mathrm{Ce} 7 / 3, \Delta \mathrm{Mn}-\mathrm{Ce} 3 / 7$ and $\square \mathrm{Mn}-\mathrm{Ce} 5 / 5$ at $25^{\circ} \mathrm{C}$

Table 4 presents the adsorption constants for Langmuir and Freundlich models. An increase is observed when the temperature rises from $25{ }^{\circ} \mathrm{C}$ to $50{ }^{\circ} \mathrm{C}$. The results of adsorption experiments show that the adsorption capacity increases with the temperature. Similar behavior has been observed by [19] when the adsorbent is graphene.
Table 5 shows the thermodynamic parameters. The adsorption equilibrium constant at infinite dilution $\left(\mathrm{K}_{0}\right)$ was calculated as:

$$
K_{0}=\frac{\gamma_{a d s} C_{a d s}}{\gamma_{e q} C_{e q}}
$$


Table 4. Adsorption Constants for $\mathrm{Mn}-\mathrm{Ce}$ series at $25^{\circ} \mathrm{C}$ and $50{ }^{\circ} \mathrm{C}$.

\begin{tabular}{|c|c|c|c|c|c|c|}
\hline \multicolumn{7}{|c|}{$25^{\circ} \mathrm{C}$} \\
\hline Sample & $\mathrm{Ka}(\mathrm{L} / \mathrm{mmol})$ & $\mathrm{qm}\left(\mathrm{mmol} / \mathrm{m}^{2}\right)$ & $\mathbf{r}^{2}$ & $\mathbf{K}_{\mathrm{F}}$ & $\mathbf{n}_{\mathrm{F}}$ & $\mathbf{r}^{2}$ \\
\hline $\mathrm{Mn}-\mathrm{Ce} 7 / 3$ & 0.287 & $2.69 * 10^{-3}$ & 0.998 & $5.73 * 10^{-4}$ & 1.6 & 0.996 \\
\hline $\mathrm{Mn}-\mathrm{Ce} 5 / 5$ & 0.270 & $1.76 * 10^{-3}$ & 0.999 & $4.07 * 10^{-4}$ & 1.9 & 0.989 \\
\hline $\mathrm{Mn}-\mathrm{Ce} 3 / 7$ & 0.382 & $1.83 * 10^{-3}$ & 0.996 & $5.94 * 10^{-4}$ & 2.4 & 0.972 \\
\hline \multicolumn{7}{|c|}{$50^{\circ} \mathrm{C}$} \\
\hline $\mathrm{Mn}-\mathrm{Ce} 7 / 3$ & 0.311 & $9.75^{*} 10^{-3}$ & 0.998 & $2.30 * 10^{-3}$ & 1.6 & 0.996 \\
\hline Mn-Ce $5 / 5$ & 0.513 & $4.19 * 10^{-3}$ & 0.998 & $1.56 * 10^{-3}$ & 2.5 & 0.997 \\
\hline $\mathrm{Mn}-\mathrm{Ce}$ 3/7 & 0.154 & $9.68 * 10^{-3}$ & 0.994 & $1.31 * 10^{-3}$ & 1.3 & 0.998 \\
\hline
\end{tabular}

Table 5. Thermodynamic Parameters of Mn-Ce at 25 and $50{ }^{\circ} \mathrm{C}$.

\begin{tabular}{|c|c|c|c|c|c|}
\hline Sample & $\mathrm{K}_{0} \mathrm{~h}\left(25^{\circ} \mathrm{C}\right)$ & $\mathrm{K}_{0} \mathrm{v}\left(25^{\circ} \mathrm{C}\right)$ & $\Delta \mathrm{G}^{0}(\mathrm{KJ} / \mathrm{mol})$ & $\Delta \mathbf{H}^{0}(\mathrm{KJ} / \mathrm{mol})$ & $\Delta \mathrm{S}^{0}\left(\mathrm{KJ} /{ }^{0} \mathrm{~K} \mathrm{~mol}\right)$ \\
\hline $\mathrm{Mn}-\mathrm{Ce} 7 / 3$ & 7.88 & 7.95 & -5.11 & 7.11 & 0.0410 \\
\hline $\mathrm{Mn}-\mathrm{Ce} 5 / 5$ & 7.42 & 7.46 & -4.96 & 6.14 & 0.0373 \\
\hline Mn-Ce 3/7 & 7.62 & 7.69 & -5.03 & 4.02 & 0.0304 \\
\hline Sample & $\mathrm{K}_{0} \mathrm{~h}\left(50^{\circ} \mathrm{C}\right)$ & $\mathrm{K}_{0} \mathrm{v}\left(50^{\circ} \mathrm{C}\right)$ & $\Delta \mathrm{G}^{0}(\mathrm{KJ} / \mathrm{mol})$ & $\Delta \mathrm{H}^{0}(\mathrm{KJ} / \mathrm{mol})$ & $\Delta \mathrm{S}^{0}\left(\mathrm{KJ} /{ }^{\circ} \mathrm{K} \mathrm{mol}\right)$ \\
\hline $\mathrm{Mn}-\mathrm{Ce} 7 / 3$ & 9.84 & 9.26 & -6.14 & 7.11 & 0.04101 \\
\hline $\mathrm{Mn}-\mathrm{Ce} 5 / 5$ & 8.99 & 9.10 & -5.89 & 6.14 & 0.03725 \\
\hline Mn-Ce 3/7 & 8.64 & 8.48 & -5.79 & 4.02 & 0.03037 \\
\hline
\end{tabular}

where $\gamma_{\text {ads }}$ and $\gamma_{\text {eq }}$ are the activity coefficients of adsorbed phenol and water, respectively; $\mathrm{C}_{\mathrm{ads}}$ is the concentration of the adsorbed species $(\mu \mathrm{g} / \mathrm{ml})$ and $C_{\text {eq }}$ is the $\mu \mathrm{g}$ of phenol per millilitre of equilibrium solution.

The value of $\mathrm{C}_{\mathrm{ads}}$ is calculated as:

$$
C_{a d s}=\frac{\left[\left(\frac{\rho_{\mathrm{H}_{2} \mathrm{O}}}{M_{\mathrm{H}_{2} \mathrm{O}}}\right) A_{\mathrm{H}_{2} \mathrm{O}}\right]}{\left[\left(\frac{S * 10^{4}}{N_{A} q_{e}}\right)-\left(\frac{A_{\text {fenol }}}{M_{\text {fenol }} * 10^{6}}\right)\right]}
$$

where $\rho_{\mathrm{H} 2 \mathrm{O}}$ is the water density $(\mathrm{g} / \mathrm{ml}), \mathrm{M}_{\mathrm{H} 2 \mathrm{O}}$ : molecular weight of water $(\mathrm{g} / \mathrm{mol}), \mathrm{M}_{\text {fenol }}$ : molecular weight of phenol (g/mol), Na: Avogadro Number, qe: amount of adsorbed phenol $(\mu \mathrm{g} / \mathrm{g})$, S: surface area of Mn-Ce sample $\left(\mathrm{m}^{2} / \mathrm{g}\right)$, $\mathrm{A}_{\mathrm{H} 2 \mathrm{O}}$ : area of water molecule $\left(\mathrm{cm}^{2} /\right.$ molec. $), \mathrm{A}_{\text {fenol }}$ : area of phenol ( $\mathrm{cm}^{2} /$ molec. $)$.

$\mathrm{K}_{0}$ was calculated assuming the adsorption of phenol can be vertical (v) or flat (f) and taking into account that the activity coefficients may change with ionic strength [20]. As constant values considering the adsorption of phenol on flat and vertical mode differ by less than $1 \%$, for performing calculations of $\Delta \mathrm{G}^{0}=-\mathrm{RT} \ln \mathrm{K}_{0}, \Delta \mathrm{H}^{0}$ with Van't Hoff equation and $\Delta \mathrm{S}^{0}=\left(\Delta \mathrm{H}^{0}-\Delta \mathrm{G}^{0}\right)^{*} \mathrm{~T}^{-1}$ [22] we took $\mathrm{K}_{0} \mathrm{~h}$ value and found that for $25^{\circ} \mathrm{C}$ and $50^{\circ} \mathrm{C}$ the constant adsorption equilibrium varies by no more than $4 \%$.

The negative values of free energy change at both temperatures. This indicates that the process is spontaneous; a more negative value results in a higher adsorption capacity. The positive value of the enthalpy change indicates that the interaction between adsorbed phenol and the surface is an endothermic process and the positive value of entropy change suggests an increased randomness in the adsorbentsolution interface during this process [19] [21]. We considered that the change of $\Delta \mathrm{S}^{0}$ value is related to some structural changes in both adsorbates and adsorbents during the adsorption process, which could be due to the different MnCe interaction in each sample.

\section{CONCLUSION}

Manganese and cerium composite oxides were prepared by alkaline coprecipitation. Structure analysis by XRD showed the formation of different $\mathrm{MnOx}$ and $\mathrm{CeO}_{2}$ solids. The average oxidation state in the solids is close to 3.5. The FTIR study demonstrated that the $\mathrm{MnO}_{6}$ octahedron is distorted. This distortion can be associated with the formation of a solid solution and a strong Mn-Ce interaction, as is evidenced by XPS. Sample 7/3 has a high adsorption capacity, whereas the monometallic samples do not absorb. Negative values of the change in free energy indicate that the 
adsorption of phenol on $\mathrm{Mn}-\mathrm{Ce}$ solids is spontaneous. Changes in $\Delta \mathrm{H}$ indicate positive values, and therefore, the adsorption mechanism is found to be endothermic. The positive values of $\Delta S$ for phenol suggest that randomness increases during adsorption. The results suggested that the adsorption capacity of the Mn-Ce samples is a function of the presence of both metals.

\section{CONFLICT OF INTEREST}

The authors confirm that this article content has no conflicts of interest.

\section{ACKNOWLEDGEMENTS}

Authors wish to thank UNLP and CONICET for financial supporting this research and Ms. Graciela M. Valle for FTIR study.

\section{REFERENCES}

[1] Stahl, R. The genetic toxicology of organic compounds in natural waters and wastewaters. Ecotox. Environ. Safe., 1991, 22 (1), 94125.

[2] Busca, G.;Berardinelli S.; Resini C.; Arrighi L. Technologies for the removal of phenol from fluid streams: A short review of recent developments. J. Hazard. Mater., 2008, 160 (2-3), 265-288.

[3] Hamoudi, S.; Larachi, F.; Sayari, A. Wet Oxidation of Phenolic Solutions over Heterogeneous Catalysts: Degradation Profile and Catalyst Behavior. J. Catal., 1998, 177 (2), 247-258.

[4] Imamura, S. Catalytic and Noncatalytic Wet Oxidation. Ind. Eng. Chem. Res., 1999, 38 (5),1743-1753.

[5] Pirkanniemi, K.; Sillanpaa, M. Heterogeneous water phase catalysis as an environmental application: a review. Chemosphere, 2002, 48(10), 1047-1060.

[6] Hamoudi, S.; Sayari, A.; Belkacemi, K.; Bonneviot, L.; Larachi, F. Catalytic wet oxidation of phenol over $\mathrm{Pt}_{\mathrm{x}} \mathrm{Ag}_{1-\mathrm{x}} \mathrm{MnO}_{2} / \mathrm{CeO}_{2}$ catalysts. Catal. Today, 2000, 62 (4), 379-388.

[7] D'Alessandro, O.; Thomas, H. J.; Sambeth, J. E. An analysis of the first steps of phenol adsorption-oxidation over coprecipitated MnCe catalysts: a DRIFTS study. Reac. Kinet. Mech. Cat., 2012, 107 (2) 295-309.
[8] Terribile, D.; Trovarelli, A.; de Leitenburg, C.; Primavera, A.; Dolcetti, G. Catalytic combustion of hydrocarbons with $\mathrm{Mn}$ and Cu-doped ceria-zirconia solid solutions. Catal. Today, 1999, 47 (14), 133-140.

[9] Julien, C. M.; Massot, M. Spectroscopic studies of the structural transitions in positive electrodes for lithium batteries. J. Power Sources, 2003, 119, 743-748.

[10] Gadsden, J. A. In: Infrared spectra of minerals and related inorganic compounds, Butterworths: England, 1975.

[11] Tseng, T.K.; Chu, H.; Hsu, H.H. Characterization of $\gamma$-AluminaSupported Manganese Oxide as an Incineration Catalyst for Trichloroethylene. Environ. Sci. Technol., 2003, 37(1), 171-176.

[12] Ferrandon, M.; Carno, J.; Jaras, S.; Bjornbom, E. Total oxidation catalysts based on manganese or copper oxides and platinum or palladium I: Characterisation. Appl. Catal. A-Gen., 1999, 180 (12), 141-151.

[13] Oku, M. X-ray photoelectron spectra of $\mathrm{KMnO}_{4}$ and $\mathrm{K}_{2} \mathrm{MnO}_{4}$ fractured in situ. J. Electron Spectrosc. Relat. Phenom, 1995, 74 (2), 135-148.

[14] Döbber, D.; Kiebling, D.; Schmitz, W.; Wendt, G. MnOx/ $/ \mathrm{ZrO}_{2}$ catalysts for the total oxidation of methane and chloromethane. Appl. Catal. B-Environ., 2004, 52 (2), 135-143.

[15] Larachi, F.; Pierre, J.; Adnot, A.; Bernis, A. Ce 3d XPS study of composite $\mathrm{Ce}_{\mathrm{x}} \mathrm{Mn}_{1-\mathrm{x}} \mathrm{O}_{2-\mathrm{y}}$ wet oxidation catalysts. Appl. Surf. Sci., 2002, 195 (1-4), 236-250.

[16] Beche, E.; Charvin, P.; Perarnau, D.; Abanades, S.; Flamant, G. Ce $3 \mathrm{~d}$ XPS investigation of cerium oxides and mixed cerium oxide $\left(\mathrm{Ce}_{\mathrm{x}} \mathrm{Ti}_{\mathrm{y}} \mathrm{O}_{\mathrm{z}}\right)$. Surf. Interface Anal., 2008, 40 (3-4), 264-267.

[17] Chen, H.; Sayari, A.; Adnot, A.; Larachi, F. Composition-activity effects of $\mathrm{Mn}-\mathrm{Ce}-\mathrm{O}$ composites on phenol catalytic wet oxidation. Appl. Catal. B-Environ., 2001, 32 (3), 195-204.

[18] O'Connell, M.; Morris, M.A. New ceria-based catalysts for pollution abatement. Catal. Today, 2000, 59(3-4), 387-393.

[19] Li, Y.; Du, Q.; Liu, T.; Sun, J.; Liao, Y.; Xia, Y.; Xia, L.; Wang, Z.; Zhang, W.; Wang, K.; Zhu, H.; Wu, D. Equilibrium, kinetic and thermodynamic studies on the adsorption of phenol onto graphene. Mater. Res. Bull., 2012, 47 (8), 1898-1904.

[20] Linares, J.; Huertas, F.; Caballero, E.; Jimenez, de Cisneros, C. Physicochemical relationships during a KCl-bentonite hydrothermal reaction. Clay Min.,1998, 33 (3), 475-482.

[21] Nuhoglu, Y.; Malkoc, E. Thermodynamic and kinetic studies for environmentaly friendly $\mathrm{Ni}(\mathrm{II})$ biosorption using waste pomace of olive oil factory. Bioresour. Technol., 2009, 100(8), 2375-2380.

[22] Niwas, R.; Gupta, U.; Khan, A.A. Varshney K.G. The adsorption of phosphamidon on the surface of styrene supported zirconium (IV) tungstophosphate: a thermodynamic study. Colloid Surf. APhysicochem. Eng. Asp., 2000, 164 (2-3), 115-119. 